\title{
Direct activation of the human major vault protein gene by DNA-damaging agents
}

\author{
YUICHI SHIMAMOTO ${ }^{1,2^{*}}$, TOMOYUKI SUMIZAWA ${ }^{1 *}$, MISAKO HARAGUCHI $^{1}$, TAKENARI GOTANDA ${ }^{1}$, \\ HEI-CHEUL JUENG ${ }^{1}$, TATSUHIKO FURUKAWA ${ }^{1}$, RYUZO SAKATA ${ }^{2}$ and SHIN-ICHI AKIYAMA ${ }^{1}$ \\ ${ }^{1}$ Department of Molecular Oncology, ${ }^{2}$ Department of Thoracic and Cardiovascular Surgery, Hepato-Billiary-Pancreatic \\ Surgery, Graduate School of Medical and Dental Sciences, Kagoshima University, Kagoshima, Japan
}

Received August 22, 2005; Accepted October 21, 2005

\begin{abstract}
Vaults are barrel-shaped cytoplasmic ribonucleoprotein particles composed of three proteins. One of the components, the major vault protein (MVP) initially named the lung resistance-related protein (LRP), was found to be overexpressed in various multidrug resistant cancer cell lines and clinical samples. In this study, we investigated whether anticancer drugs could directly induce MVP protein or gene expression in the SW-620 human colorectal cancer cell line, in which MVP has been shown to be induced by the differentiation-inducing agent, sodium butyrate (NaB). MVP protein levels were enhanced in SW-620 cells after a $72 \mathrm{~h}$ treatment with doxorubicin (Adr), etoposide (VP-16), cis-platinum (II) diammine dichloride (CDDP) or SN-38, but not vincristine (VCR) or paclitaxel (Taxol) at their $\mathrm{IC}_{50}$ concentration. Treatment for $48 \mathrm{~h}$ with Adr, VP-16 and $\mathrm{SN}-38$ at their $\mathrm{IC}_{50}$ concentration also enhanced the expression of MVP mRNA. Moreover, Adr could directly enhance the transcriptional activity of MVP promoter regions. On the other hand, the Adr treatment did not affect the stability of MVP mRNA. Furthermore, MVP levels were also elevated after treatment with the DNA-damaging agents, ethidium bromide (EtBr) and ultraviolet light (UV) irradiation. Our
\end{abstract}

Correspondence to: Dr Tomoyuki Sumizawa, Institute of Industrial Ecological Sciences, University of Occupational and Environmental Health, 1-1 Iseigaoka, Yahatanishi, Kitakyushu 807-8555, Japan E-mail: t-smzw@med.uoeh-u.ac.jp

${ }^{*}$ Contributed equally

Abbreviations: MDR, multidrug resistance; P-gp, P-glycoprotein; LRP, lung resistance-related protein; MVP, major vault protein; VPARP, vault poly(ADP-ribose) polymerase; TEP1, telomeraseassociated protein; Adr, doxorubicin; VP-16, etoposide; VCR, vincristine; CDDP, cis-platinum (II) diammine dichloride; Taxol, paclitaxel; YB-1, Y-box binding protein; 5-FU, 5-fluorouracil; $\mathrm{NaB}$, sodium butyrate; TSP-1, thrombospondin-1; EtBr, ethidium bromide; UV, ultraviolet light; BRCT, BRCA 1 C-terminus domain

Key words: major vault protein/lung resistance-related protein, multidrug resistance, anticancer agent, DNA damage, gene expression findings therefore suggest that DNA damage enhances MVP promoter activity. Since the MVP protein and mRNA have low turnover rates, a slight enhancement of MVP promoter activity could lead to a considerable increase in the level of MVP.

\section{Introduction}

Multidrug resistance (MDR) in cancer cells is a major obstacle to successful chemotherapy. Some drug transporter proteins, such as $\mathrm{P}$-glycoprotein (P-gp) encoded by MDRl and multidrug resistance protein-1, have been found to be associated with MDR. Additional mechanisms have also been implicated in the MDR phenotype of cancer cells. One non-transporter protein that may play a role in MDR is the $110-\mathrm{kDa}$ protein frequently overexpressed in P-glycoproteinnegative multidrug-resistant tumor cell lines, initially termed the lung resistance-related protein (LRP) (1). LRP is now known to be identical to a human protein termed the major vault protein (MVP) (2). Vaults are predominantly cytoplasmic ribonucleoprotein particles originally identified in preparations of coated vesicles (3), and conserved throughout evolution and found in numerous eukaryotic species (4). The vault complex has a barrel-like structure with an invaginated waist and two protruding caps. Mammalian vaults are composed of MVP and two minor vault proteins [vault poly(ADP-ribose) polymerase (VPARP), and telomeraseassociated protein (TEP1)], as well as small untranslated RNAs (5-7). The precise cellular function of the vault complex is unknown, although its structural features suggest a role in intracellular transport processes (8).

Several lines of evidence suggest a role for MVP in modulating drug resistance. MVP, as well as the vault particle, are overexpressed in drug-resistant cell lines $(9,10)$. Furthermore, MVP levels are enhanced in cancer cell lines selected with the anticancer drugs doxorubicin (Adr), mitoxantrone, etoposide (VP-16), vincristine (VCR), cytarabine, cis-platinum (II) diammine dichloride (CDDP) and bleomycin (11-16). The human MDR1 promoter can be directly activated by various anticancer agents (17). DNA sequences that contain an inverted CCAAT box and a Y-box constitute cis-regulatory elements common to various eukaryotic genes (18). The Y-box binding protein (YB-1) is a member of the cold-shock domain protein family. Most of 
the YB-1 molecules are localized in the cytoplasm and translocated to the nuclei when cells are exposed to various stresses, such as anticancer agents, hyperthermia or ultraviolet light (UV) (19-21). A Y-box resides in the promoter region of the $M D R 1$ gene (22), and the YB-1 protein regulates the activity of the $M D R 1$ gene $(22,23)$. A Y-box is also present in the human MVP gene promoter (24), and YB-1 facilitates basal and 5-fluorouracil (5-FU)-inducible expression of the human MVP gene (25).

In the present study, we investigated whether anticancer drugs can induce MVP gene expression in the human colorectal cancer cell line, SW-620, in which MVP can be induced by the differentiation-inducing agent sodium butyrate $(\mathrm{NaB})(26)$. We further investigated potential mechanisms by which anticancer drugs modulate MVP gene expression.

\section{Materials and methods}

Materials. RPMI-1640 medium was purchased from Nissui Seiyaku Co. (Tokyo, Japan), fetal calf serum (FCS) was from JRH Biosciences (Lenexa, KS), and 3-(4,5-dimethylthiazol2-yl)-2,5-diphenyltetrazolium bromide (MTT), Adr, VP-16, CDDP, VCR, paclitaxel (Taxol) and $\mathrm{NaB}$ were obtained from Sigma Chemical Co. (St. Louis, MO). SN-38 was kindly provided by Daiichi Pharmaceutical Co. Ltd. and Yakult Pharmaceutical Ind. Co. Ltd. (Tokyo, Japan). The $\alpha-$ amanitin was purchased from Wako Pure Chemical Industries Ltd. (Osaka, Japan).

Cell culture and cell survival analyses. SW-620, a human colon carcinoma cell line, was grown in RPMI-1640 medium containing $10 \% \mathrm{FCS}$ in a humidified atmosphere of $5 \% \mathrm{CO}_{2}$ at $37^{\circ} \mathrm{C}$. Sensitivity of the cells to the various agents tested was analyzed by determining cell survival using the MTT colorimetric assay as previously described (27). Briefly, $1 \times 10^{4}$ SW-620 cells in $180 \mu 1$ of culture medium were inoculated into each well of a 96-well plate. After an overnight incubation at $37^{\circ} \mathrm{C}, 20 \mu \mathrm{l}$ of anticancer drugs at various concentrations were added to each well, and the cultures were incubated for 3 days at $37^{\circ} \mathrm{C}$ in $5 \% \mathrm{CO}_{2}$. Thereafter, $50 \mu 1$ of MTT $(2.5 \mathrm{mg} / \mathrm{ml}$ PBS $)$ was added to each well, and the cultures were incubated for an additional $4 \mathrm{~h}$. The resulting formazan was dissolved with $100 \mu \mathrm{l}$ of dimethylsulfoxide after aspiration of the culture medium. Absorbance at $570 \mathrm{~nm}$ was measured using a model 550 microplate reader (Bio-Rad, Richmond, CA).

Preparation of total cell lysates and immunoblot analysis of MVP. SW-620 cells were treated with anticancer drugs, ethidium bromide or UV under the indicated conditions. Total cell lysates were separated by $6 \%$ SDS-polyacrylamide gel electrophoresis (SDS-PAGE), and the expression level of MVP was analyzed by immunoblot analysis using an antiMVP polyclonal antibody $(26,28)$.

Real-time reverse-transcription PCR quantification. SW-620 cells were plated $\left(2 \times 10^{6} /\right.$ dish) in 100 -mm plastic dishes and treated with or without anticancer drugs at their $\mathrm{IC}_{50}$ concentration (the concentration that inhibits cell growth by $50 \%$ ) for $48 \mathrm{~h}$. Total RNA from the cultured cells was isolated
A

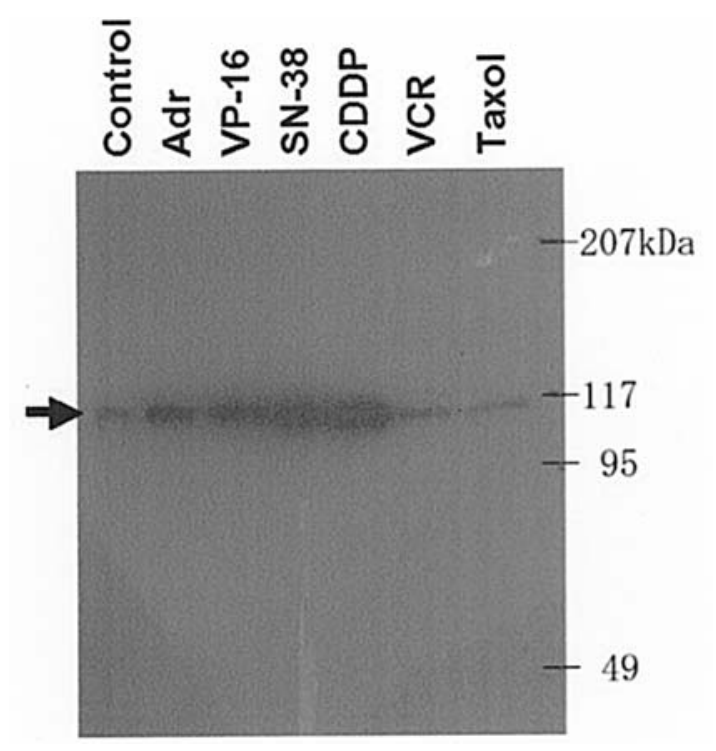

$\mathbf{B}$

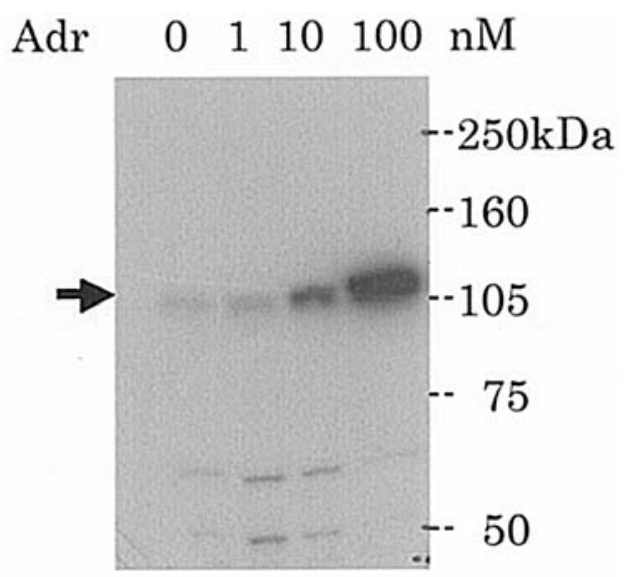

C

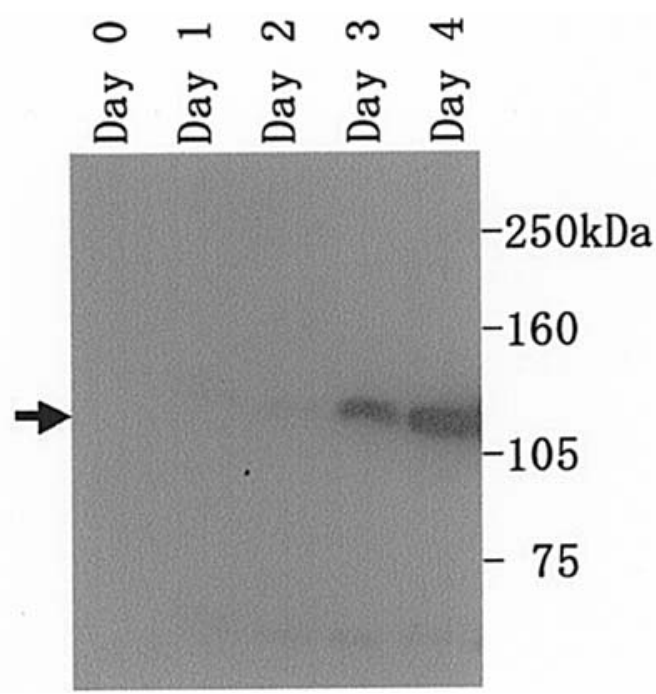

Figure 1. Regulation of MVP protein expression by anticancer agents. MVP protein expression in SW-620 cells was assayed by immunoblot analysis following $72 \mathrm{~h}$ continuous exposure to the anticancer agents Adr, VP-16, SN-38, CDDP, VCR or Taxol at their $\mathrm{IC}_{50}$ concentration (A); $72 \mathrm{~h}$ continuous exposure to 1,10 , and $100 \mathrm{nM} \mathrm{Adr}(\mathrm{B})$; or exposure to $\mathrm{Adr}$ at its $\mathrm{IC}_{50}$ concentration over 4 days (C). MVP is indicated by an arrow at left, and molecular weight markers are on the right.

using the Trizol reagent (Invitrogen, Carlsbad, CA) and cDNA was synthesized from $1 \mu \mathrm{g}$ of total RNA with ReverTra Ace $\alpha$ (Toyobo, Osaka, Japan) using a random primer according to 
A

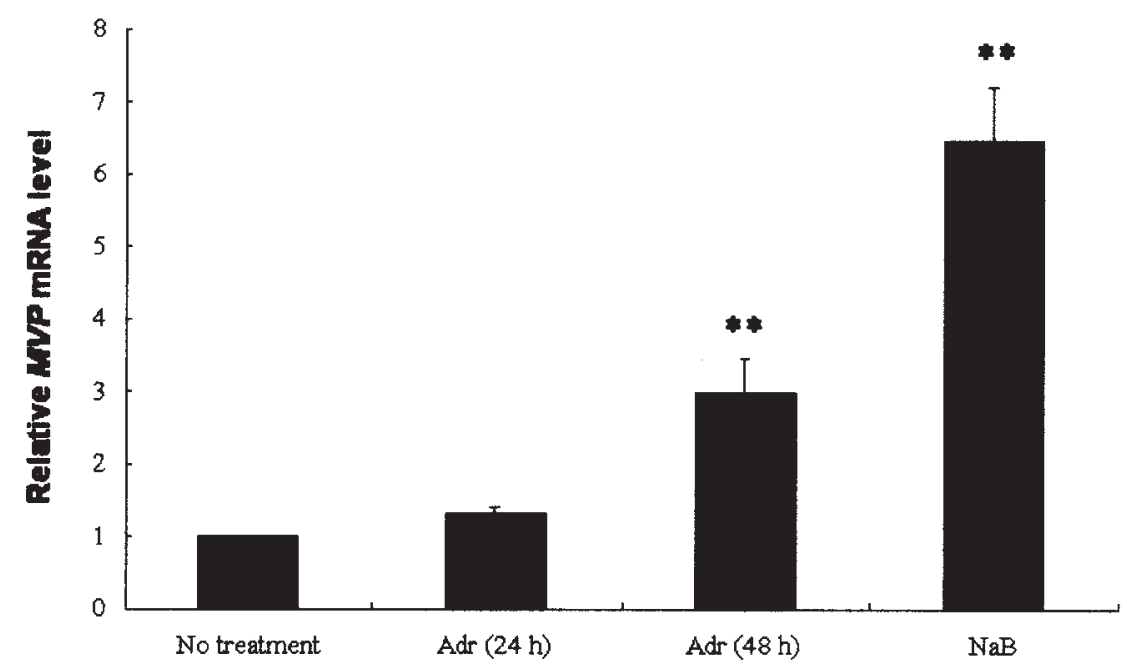

$\mathbf{B}$

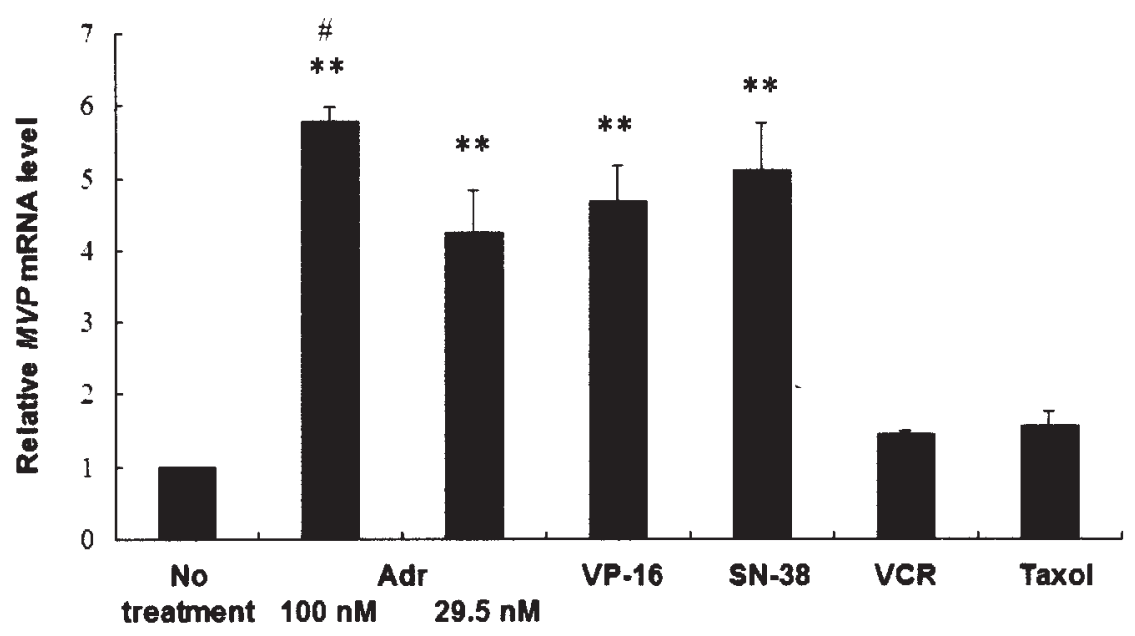

Figure 2. MVP mRNA levels are enhanced by anticancer agents. The effect of anticancer drugs on $M V P$ mRNA levels was assayed by real-time PCR analyses in SW-620 cells. Relative expression levels of MVP mRNA were normalized to GAPDH mRNA expression. (A) Cells were cultured with or without $100 \mathrm{nM}$ Adr for 24 or $48 \mathrm{~h}$, or with $2 \mathrm{mM} \mathrm{NaB}$ for $24 \mathrm{~h}$ as a positive control. (B) Cells were continuously incubated for $48 \mathrm{~h}$ with or without $100 \mathrm{nM}$ Adr, or with Adr, VP-16, SN-38, VCR or Taxol at their $\mathrm{IC}_{50}$ concentration. Each column and bar represents the mean \pm standard deviations (error bars) of three independent experiments. ${ }^{* *} \mathrm{p}<0.01$ versus no treatment. ${ }^{\#} \mathrm{p}<0.05$ versus treatment with $\mathrm{Adr}$ at $\mathrm{IC}_{50}$.

the manufacturer's protocol. MVP gene expression levels were assayed by real-time PCR (Prism 7900HT; Applied Biosystems, Foster City, CA) according to the manufacturer's protocol. The primers and TaqMan probe used were: forward, 5'-GCGCGCTGTGATTGGAA-3'; reverse, 5'CCGGGAGGCAGCTCTTTC-3'; and TaqMan probe, 5'FAM-CATGCTGACCCAGGACGAAGTCCTGT-Tamra-3', which were designed with the primer design software Primer Express version 1.5 (Applied Biosystems). Human glyceraldehyde-3-phosphate dehydrogenase (GAPDH) was used for normalization. Relative quantification of GAPDH and MVP mRNA was calculated using a comparative cycle threshold method. Triplicate samples were used for each data point. Data was quantified with a standard curve method (29).

Cloning of the 5'-flanking region of the human MVP promoter and reporter gene constructs. Human MVP promoters expressing a series of 5 ' deletions ranging from $-407,-315$, $-263,-102$ or -78 to +66 were amplified from the genomic DNA of SW-620 cells by PCR with Ex Taq (Takara Bio, Ohtsu, Japan). The upstream PCR forward primers incorporated a 5'-flanking $\mathrm{KpnI}$ restriction site (underlined), and the sequences of the primers were 5'-CCGGTACCT GGACTGAATTTTCTGAG-3'; 5'-AGGTACCACTTGAAG GGAGAGGCAGAAT-3'; 5'-TGGTACCAGATGGGTAGA GGTGCCCTCA-3'; 5'-TAGGTACCTGAGAACCAGCTG CACA-3' and 5'-ATGGTACCTTTAACTCCCAAGCCCCA-3' for promoter constructs spanning $-407 /+66,-315 /+66,-263 /$ $+66,-102 /+66$ and $-78 /+66$, respectively. The downstream reverse primer, flanked by the SacI site (underlined), was 5'AGAGCTCGGGGCTAGTACAATGTACTCACA-3'. The PCR products were cloned into pT7Blue-2 vector (Merck Biosciences, San Diego, CA), then sequenced. Following digestion with KpnI and SacI, 472 bp, 380 bp, 328 bp, 167 bp and 143 bp MVP promoter fragments were gel-purified and ligated into the KpnI and SacI-linearized pGL3-basic vector (Promega, Madison, WI). The resulting constructs were designated pMVP407, pMVP315, pMVP263, pMVP102 and pMVP78, respectively.

Transfection and luciferase assay. Transient transfection of SW-620 cells with a luciferase reporter plasmid was carried 
A

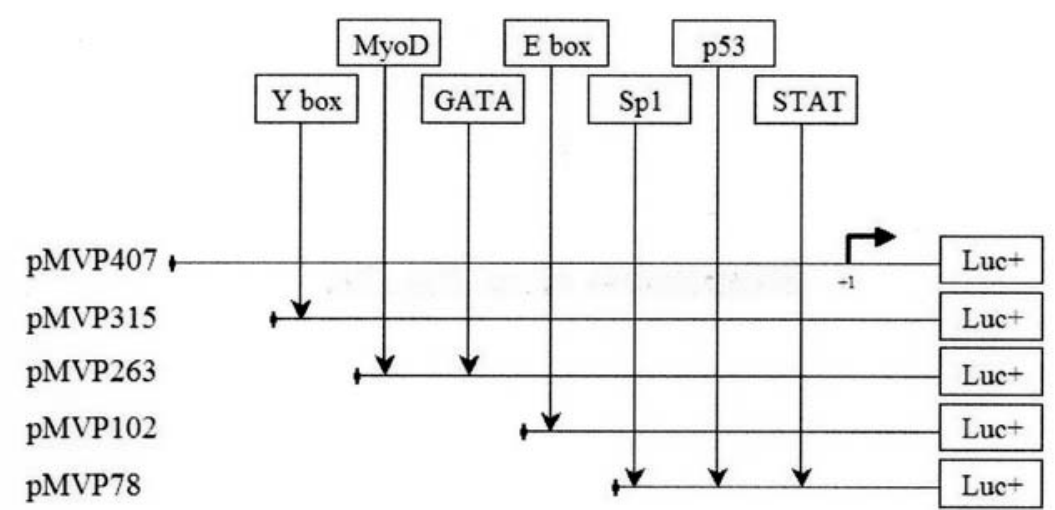

B

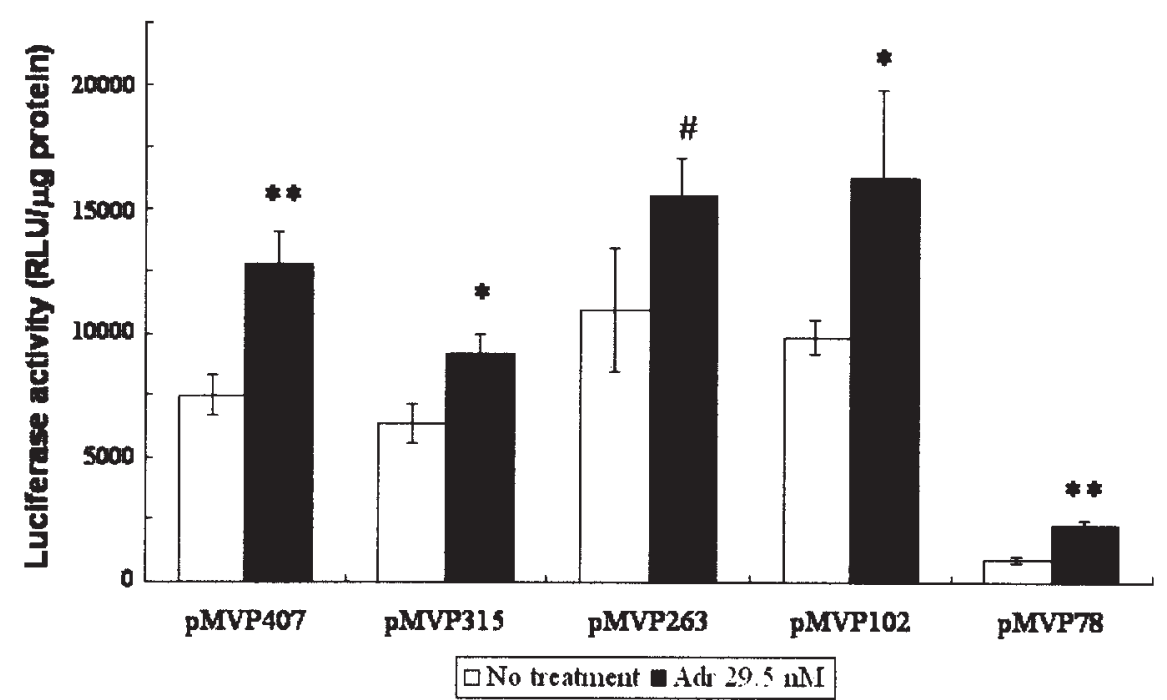

Figure 3. The role of MVP promoter elements for Adr modulation of MVP promoter activity. Transcriptional activity was assayed using luciferase (luc+)based reporter constructs bearing various deletions of the MVP promoter region. A schematic representation of the MVP promoter deletion constructs used in this study is shown (A). SW-620 cells, which were transiently transfected with these constructs using lipofectamine reagent, were harvested after $48 \mathrm{~h}$ continuous exposure to $\mathrm{Adr}$ at its $\mathrm{IC}_{50}$ concentration, and their luciferase activities were measured (B). Data were normalized to the protein concentration. Each column and bar represents the mean \pm standard errors of three independent experiments. The symbols represent a comparison of the data versus untreated basal luciferase activity measured for each deletion construct $\left({ }^{*} \mathrm{p}<0.05,{ }^{* *} \mathrm{p}<0.01\right.$ or $\left.{ }^{*} \mathrm{p}=0.0537\right)$.

out using lipofectamine reagent (Invitrogen) according to the manufacturer's protocol. Luciferase assays were performed $48 \mathrm{~h}$ after transfection. The determined protein concentration was used for the normalization of luciferase activity.

Measurement of mRNA stability. Cells were plated at a density of $2 \times 10^{6}$ cells in 6-well plates and incubated in medium without serum for $24 \mathrm{~h}$ after which the medium was removed and replaced with medium containing serum. After $4 \mathrm{~h}$ incubation, medium was removed and replaced with serum-free medium containing $\alpha$-amanitin (5 $\mu \mathrm{g} / \mathrm{ml})$ (30) with or without $\mathrm{Adr}$ at its $\mathrm{IC}_{50}$ concentration. Total RNA was isolated as described above at the indicated times after treatment with $\alpha$-amanitin. Subsequently, real-time reversetranscription PCR quantification was performed as mentioned above. Expression levels of thrombospondin-1 (TSP-1) mRNA were used as positive controls. Experiments were performed in triplicate for each data point.

\section{Results}

Regulation of MVP protein expression by anticancer agents. We investigated if various anticancer agents could induce
MVP expression in SW-620 cells. We first established the cytotoxic effect of the anticancer agents by determining the survival of SW-620 cells following treatment with the various agents using the MTT assay. $\mathrm{IC}_{50}$ values for Adr, VP-16, SN-38, CDDP, VCR and Taxol were $29.5 \mathrm{nM}, 771 \mathrm{nM}$, $15.8 \mathrm{nM}, 6.10 \mu \mathrm{M}, 8.22 \mathrm{nM}$ and $13.5 \mathrm{nM}$, respectively (data not shown).

We next examined whether these anticancer drugs could enhance the expression of the MVP protein. SW-620 cells were continuously incubated for $72 \mathrm{~h}$ with each anticancer agent at its $\mathrm{IC}_{50}$ concentration, and the drug-mediated modulation of MVP expression was investigated by immunoblot analysis (Fig. 1A). MVP protein levels were unchanged, or even decreased, when cells were treated with VCR or Taxol. In contrast, treatment with Adr, VP-16, SN-38 or CDDP dramatically enhanced MVP expression compared to untreated SW-620 cells.

To test whether MVP protein is induced by these agents in a dose-dependent manner, we cultured SW-620 cells for 3 days in the medium containing $\mathrm{Adr}$ at doses of 1,10 or $100 \mathrm{nM}$. As shown in Fig. 1B, increasing doses of Adr induced increasing levels of MVP protein. Similar results were obtained following treatment with CDDP (data not shown). 


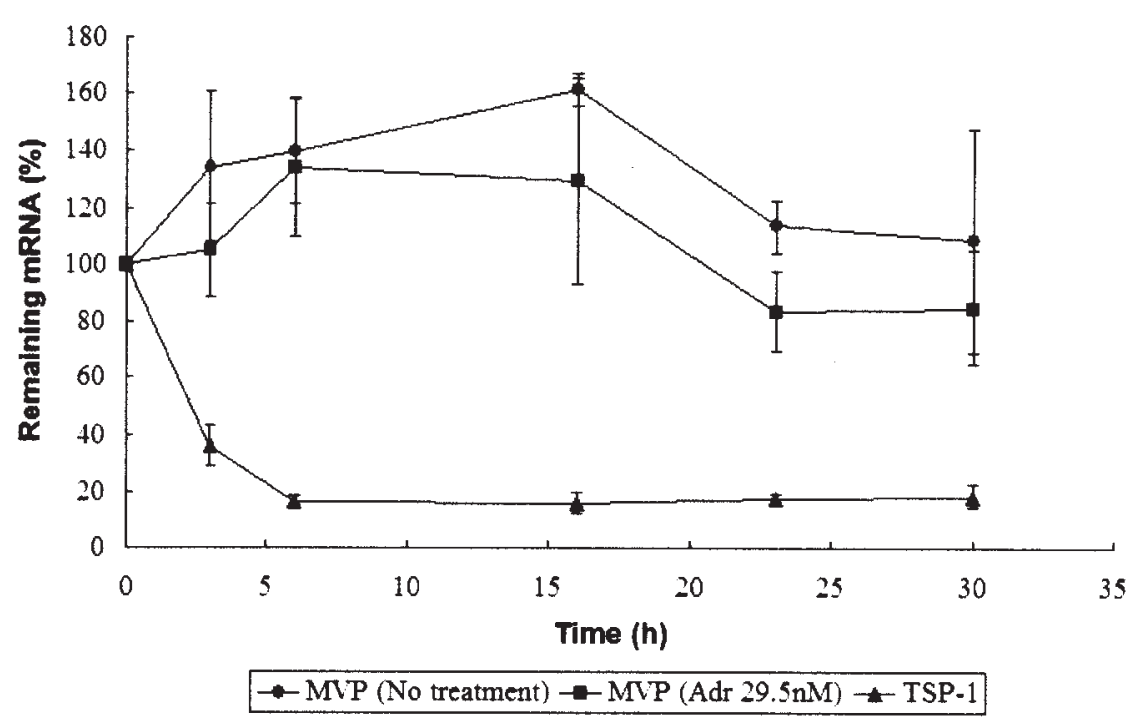

Figure 4. The effect of Adr on the stability of $M V P$ mRNA in SW-620 cells. Expression levels of $M V P$ mRNA in the absence (circles) or presence (squares) of Adr treatment were analyzed at the indicated periods $(\mathrm{h})$ as described in Fig. 2. The expression of TSP-1 mRNA (triangles) was used as a positive control. Points represent the means \pm standard deviations (error bars) of three independent experiments.

Subsequently, we monitored the time dependence of MVP expression following the addition of $\mathrm{Adr}$ at $29.5 \mathrm{nM}\left(\mathrm{IC}_{50}\right.$ concentration). Induction of the MVP protein was detectable on day 2 and enhanced by day 3. This enhanced level of MVP expression was maintained into day 4 (Fig. 1C). Thus, MVP protein is regulated by anticancer drugs in a dose- and time-dependent manner.

Regulation of MVP mRNA levels by anticancer agents. We determined if enhanced MVP transcription could contribute to the increased MVP protein levels following Adr treatment. The effect of Adr on MVP mRNA expression levels in SW-620 cells was investigated by TaqMan real-time reversetranscription PCR. Induction of $M V P$ mRNA with $\mathrm{NaB}$ was used as a positive control (26), and untreated cells were used as a negative control. The $100 \mathrm{nM}$ Adr did not significantly increase MVP mRNA in SW-620 cells after $24 \mathrm{~h}$, even though $M V P$ mRNA levels were significantly enhanced at this time point by $2 \mathrm{mM} \mathrm{NaB}$ compared to non-treated controls $(\mathrm{p}<0.0001)$. However, Adr did significantly increase the level of MVP mRNA in SW-620 cells $(\mathrm{p}<0.01)$ following treatment for $48 \mathrm{~h}$ (Fig. 2A). This delayed induction of MVP mRNA by Adr compared to $\mathrm{NaB}$ is consistent with the delayed induction of MVP protein by Adr (Fig. 1C) compared to that reported for $\mathrm{NaB}$ (26).

We then tested if other anti-cancer agents could affect $M V P$ mRNA levels following $48 \mathrm{~h}$ treatment. SW-620 cells were incubated continuously for $48 \mathrm{~h}$ with $\mathrm{Adr}, \mathrm{VP}-16, \mathrm{SN}-38$, VCR or Taxol at their $\mathrm{IC}_{50}$ concentration, and MVP mRNA levels were determined in comparison to non-treated cells (Fig. 2B). In addition to Adr, both VP-16 and SN-38 significantly $(\mathrm{p}<0.0001)$ enhanced MVP mRNA levels, whereas VCR $(p=0.9236)$ and Taxol $(p=0.8085)$ had no significant effect.

These findings indicate that a number of anti-cancer drugs, including Adr, VP-16 and SN-38, can induce increased MVP mRNA levels. Data for the different Adr concentrations further confirm the dose-dependent effect of Adr on MVP protein expression suggested by Fig. 1B.
Activation of the MVP promoter by Adr. One likely mechanism by which Adr might enhance $M V P$ mRNA levels is by the modulation of $M V P$ promoter activity. To assess whether Adr can activate $M V P$ promoter activity, we generated five luciferase reporter constructs with a series of $M V P$ promoter regions containing various promoter elements. The longest constructs, pMVP407 and pMVP315, contain all known conserved promoter elements, i.e. Y-box, MyoD, GATA, E-box, Sp1, p53 and STAT (24). The construct pMVP263 lacks only a Y-box, and MyoD and GATA are further deleted in pMVP102. The shortest construct, pMVP78, lacks all of these elements except Sp1, p53 and STAT (Fig. 3A). Cells individually transfected with these plasmids were then treated with $\mathrm{Adr}$ at its $\mathrm{IC}_{50}$ concentration, and the ability of Adr treatment to induce luciferase activity of the reporter gene was assayed. Adr treatment increased luciferase activity 1.7-, 1.4-, 1.4-, 1.6- and 2.6-fold compared to the basal luciferase activity in pMVP407, pMVP315, pMVP263, pMVP102 and pMVP78-transfected cells, respectively (Fig. 3B). These data suggest that enhancement of transcriptional activity can contribute to the induction of elevated MVP mRNA levels by Adr. The basal luciferase activity of pMVP78 was significantly lower than that of other constructs $(\mathrm{p}<0.05)$ suggesting that this construct may lack promoter elements essential for basal MVP promoter activity (Fig. 3B).

The effect of Adr on the stability of MVP mRNA. Although Adr activates $M V P$ promoter activity, the observed level of enhancement could not fully account for the enhanced level of MVP mRNA and protein expression measured. We therefore tested if Adr could employ other mechanisms to enhance MVP levels; one possibility was that Adr might also affect the stability of MVP mRNA. We treated SW-620 cells with Adr in the presence of the RNA polymerase II inhibitor $\alpha$-amanitin to prevent further mRNA synthesis and measured MVP mRNA levels by real-time reverse-transcription PCR. MVP mRNA was stable and not degraded in untreated and Adr-treated SW-620 cells over a period of $30 \mathrm{~h}$ (Fig. 4). Adr treatment did not affect the MVP mRNA stability. In contrast, 


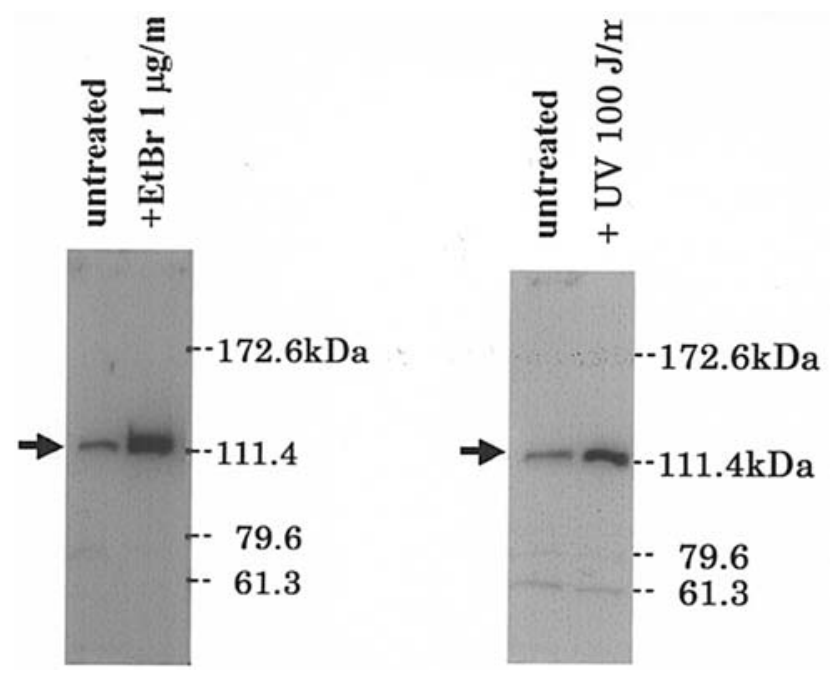

Figure 5. Effect of UV irradiation and EtBr treatment on MVP protein expression. SW-620 cells were continuously incubated with $\mathrm{EtBr}(1 \mu \mathrm{g} / \mathrm{ml}$, left) or exposed to UV irradiation (100 J/m² , right) for $72 \mathrm{~h}$. MVP protein expression was then assessed by immunoblotting. MVP protein is indicated by an arrow at left, and molecular weight markers are on the right.

TSP-1 mRNA, which was assayed as a control, was degraded with a half-life of $2.5 \mathrm{~h}$ in untreated cells, and similar results were obtained with matrix metalloproteinase-9 mRNA (data not shown). Although the data do not indicate a dramatic increase in the stability of $M V P$ mRNA by Adr, the unexpected stability of MVP over a period of $30 \mathrm{~h}$ suggests that a small increase in $M V P$ promoter activity could result in a relatively large increase in MVP expression.

Correlation between MVP expression and DNA damage. We have shown that MVP expression is enhanced by Adr, VP-16, SN-38 or CDDP treatment, but not VCR and Taxol (Fig. 1A). Since all of the agents that elevated MVP expression were DNA damaging agents, we next assessed whether DNA damage induced by UV irradiation or ethidium bromide $(\mathrm{EtBr})$ treatment could also increase MVP expression levels.

SW-620 cells were incubated for $72 \mathrm{~h}$ after irradiation with UV at $100 \mathrm{~J} / \mathrm{m}^{2}$ or continuously exposed to EtBr at $1 \mu \mathrm{g} / \mathrm{ml}$, and MVP expression in the treated cells was compared to that in untreated cells by immunoblot analysis (Fig. 5). Both treatments markedly enhanced MVP expression. These data therefore suggest that MVP expression can be induced by a variety of agents inducing DNA damage.

\section{Discussion}

Human MVP (originally termed LRP) was first described as a protein found in a non-P-gp-mediated multidrug-resistant non-small cell lung cancer cell line selected with Adr $(1,2)$. In succeeding years, MVP was found to be overexpressed in several human multidrug-resistant tumor cell lines $(9,10,31)$, suggesting that MVP might play a role in MDR. In this study, we show that several anticancer agents induce MVP expression in the colon cancer cell line, SW-620 (Fig. 1A). This result is consistent with previously published reports of high MVP expression in cells treated with a variety of anticancer agents including Adr, mitoxantrone, methotrexate, VP-16, VCR, cytarabine, 5-FU, bleomycin and CDDP $(1,11-$ $13,15,16,25,32-37)$. We have previously demonstrated that $\mathrm{NaB}$, a histone deacetylase (HDAC) inhibitor, stimulated $M V P$ expression and enhanced drug resistance in human colon carcinoma cells (26). However, the sensitivity to anticancer agents of fibroblasts derived from MVP knockout mice is comparable to that of wild-type fibroblasts (38). Thus, the precise role of MVP and the vault particle in MDR, and their physiological role(s), are still undefined. In this study, we demonstrated the activation of $M V P$ promoter activity by Adr (Fig. 3B) and the unexpected stability of MVP mRNA (Fig. 4). Together with the previous finding that the MVP protein is highly stable (28), these data might explain the elevated MVP levels induced by anticancer agents.

In order to fully understand the regulation of $M V P$ expression, it is necessary to identify the mechanism by which $M V P$ transcription is regulated. The human $M V P$ gene promoter has been cloned and contains an inverted CCAAT-box termed the Y-box, which responds to a number of stresses including anticancer agents, UV, and hyperthermia (20,21,39-41). Nuclear localization of the Y-box binding transcription factor, YB-1, was shown to be correlated with intrinsic expression of the MDR gene 1 (MDRl) in human carcinomas and osteosarcomas $(23,42)$. Stein et al have reported the direct involvement of YB-1 in controlling basal and 5-FU-induced MVP promoter activity (25). Our results indicate that a second promoter element, termed the E-box, is essential for basal MVP promoter activity. The promoter construct pMVP78, in which the E-box was deleted from the $M V P$ promoter region, showed considerably less basal luciferase activity compared to the promoter construct pMVP102 (Fig. 3B). In contrast, deletion of the Y-box did not affect the basal MVP promoter activity (Fig. 3A and B). It has also been suggested that the consensus element for $\mathrm{Sp} 1$ transcription factor binding is critical for basal $M V P$ promoter activity and its stimulation by HDAC inhibitors (43). However, in this study, the MVP promoter construct pMVP78 that retained the Sp1 binding site could not maintain basal MVP promoter activity. The discrepancy between these data can possibly be attributed to the use of different cell types for these experiments.

We have shown that a number of anticancer agents can enhance $M V P$ promoter activity, and examined the possible elements in the MVP promoter that might be important for this enhancement. It has previously been shown that anticancer agents can variously enhance the activity of the MDRI promoter via Y-box and YB-1. Among several anticancer agents, VCR effectively activated the $M D R l$ promoter, whereas Adr only weakly activated it and VP-16 did not activate it at all (17). In contrast to their activation of the MDRl promoter, Adr and VP-16 activated the MVP gene effectively, but VCR did not (Figs. 1A and 2B). The difference in response to VCR and VP-16 between the MDRI and MVP promoters may be attributable to differences in the elements in promoter structure, and also suggests that Y-box is not essential for the induction of MVP by Adr in SW-620 cells. It is intriguing that the $M V P$ promoter is activated by DNA damaging agents alone.

The fact that deletion of the Y-box in the human MVP promoter does not affect basal MVP promoter activity in this study, coupled with the fact that the murine $M V P$ promoter 
lacks a Y-box $(44,45)$, suggests that the Y-box may not be essential for the basal expression of the $M V P$ gene. Since the murine $M V P$ promoter does have an Sp1 or E-box, and we have shown that deletion of the E-box dramatically reduces basal MVP transcriptional activity, this indicates the E-box, and not the Y-box, may be critical for basal expression of the MVP gene. However, it remains controversial whether YB-1 is directly involved in MVP expression in human tumors.

This study indicated a correlation between MVP expression and DNA damage in SW-620 cells. At present, it is unclear whether high MVP expression modulates DNA damage. It is highly likely that vault is involved in DNA damage repair because VPARP contains a BRCA 1 C-terminus (BRCT) domain that defines a superfamily of DNA damage response proteins $(46,47)$. However, vaults may not be involved in all types of DNA damage, as vaults and VPARP in the cytoplasm are not relocalized to the nucleus in response to DNA damage by UV light irradiation (6). Further investigation is required to determine whether the induction of MVP by DNA damage is common to both human and murine systems and to understand how DNA damage induces MVP expression. Extension of the studies concerning the mechanism by which MVP expression is regulated via promoter binding proteins may also shed light on the cellular function of vaults.

\section{Acknowledgements}

This work was supported by a Grant-in-Aid from the Ministry of Education, Culture, Sports, Science and Technology of Japan. We thank Ms. Hiromi Kakura for her excellent secretarial assistance, and Ms. Etsuko Sudo for her excellent technical assistance.

\section{References}

1. Scheper RJ, Broxterman HJ, Scheffer GL, et al: Overexpression of a M(r) 110,000 vesicular protein in non-P-glycoproteinmediated multidrug resistance. Cancer Res 53: 1475-1479, 1993.

2. Scheffer GL, Wijngaard PL, Flens MJ, et al: The drug resistancerelated protein LRP is the human major vault protein. Nat Med 1: 578-582, 1995 .

3. Kedersha NL and Rome LH: Isolation and characterization of a novel ribonucleoprotein particle: large structures contain a single species of small RNA. J Cell Biol 103: 699-709, 1986.

4. Kedersha NL, Miquel MC, Bittner D and Rome LH: Vaults. II. Ribonucleoprotein structures are highly conserved among higher and lower eukaryotes. J Cell Biol 110: 895-901, 1990.

5. Kickhoefer VA, Vasu SK and Rome LH: Vaults are the answer, what is the question? Trends Cell Biol 6: 174-178, 1996.

6. Kickhoefer VA, Siva AC, Kedersha NL, et al: The 193-kDa vault protein, VPARP, is a novel poly(ADP-ribose) polymerase. J Cell Biol 146: 917-928, 1999.

7. Kickhoefer VA, Stephen AG, Harrington L, Robinson MO and Rome LH: Vaults and telomerase share a common subunit, TEP1. J Biol Chem 274: 32712-32717, 1999.

8. Van Zon A, Mossink MH, Scheper RJ, Sonneveld P and Wiemer EA: The vault complex. Cell Mol Life Sci 60: 1828-1837, 2003.

9. Izquierdo MA, Shoemaker RH, Flens MJ, et al: Overlapping phenotypes of multidrug resistance among panels of human cancer-cell lines. Int J Cancer 65: 230-237, 1996.

10. Kickhoefer VA, Rajavel KS, Scheffer GL, Dalton WS, Scheper RJ and Rome LH: Vaults are up-regulated in multidrug-resistant cancer cell lines. J Biol Chem 273: 8971-8974, 1998.

11. Wyler B, Shao Y, Schneider E, et al: Intermittent exposure to doxorubicin in vitro selects for multifactorial non-P-glycoproteinassociated multidrug resistance in RPMI 8226 human myeloma cells. Br J Haematol 97: 65-75, 1997.
12. Komarov PG, Shtil AA, Holian O, et al: Activation of the LRP (lung resistance-related protein) gene by short-term exposure of human leukemia cells to phorbol ester and cytarabine. Oncol Res 10: 185-192, 1998.

13. Berger W, Elbling L and Micksche M: Expression of the major vault protein LRP in human non-small-cell lung cancer cells: activation by short-term exposure to antineoplastic drugs. Int J Cancer 88: 293-300, 2000.

14. Cheng SH, Lam W, Lee AS, Fung KP, Wu RS and Fong WF: Low-level doxorubicin resistance in benzo[a]pyrene-treated KB-3-1 cells is associated with increased LRP expression and altered subcellular drug distribution. Toxicol Appl Pharmacol 164: 134-142, 2000 .

15. Hu Y, Stephen AG, Cao J, et al: A very early induction of major vault protein accompanied by increased drug resistance in U-937 cells. Int J Cancer 97: 149-156, 2002.

16. Meschini S, Marra M, Calcabrini A, et al: Role of the lung resistance-related protein (LRP) in the drug sensitivity of cultured tumor cells. Toxicol In Vitro 16: 389-398, 2002.

17. Kohno K, Sato S, Takano H, Matsuo K and Kuwano M: The direct activation of human multidrug resistance gene (MDR1) by anticancer agents. Biochem Biophys Res Commun 165: 1415-1421, 1989.

18. Wolffe AP, Tafuri S, Ranjan M and Familari M: The Y-box factors: a family of nucleic acid binding proteins conserved from Escherichia coli to man. New Biol 4: 290-298, 1992.

19. Kohno K, Izumi H, Uchiumi T, Ashizuka M and Kuwano M: The pleiotropic functions of the Y-box-binding protein, YB-1. Bioessays 25: 691-698, 2003.

20. Stein U, Jurchott K, Walther W, Bergmann S, Schlag PM and Royer HD: Hyperthermia-induced nuclear translocation of transcription factor YB-1 leads to enhanced expression of multidrug resistance-related ABC transporters. J Biol Chem 276: 28562-28569, 2001.

21. Ohga T, Koike K, Ono M, et al: Role of the human Y boxbinding protein $\mathrm{YB}-1$ in cellular sensitivity to the DNA-damaging agents cisplatin, mitomycin C, and ultraviolet light. Cancer Res 56: 4224-4228, 1996.

22. Uchiumi T, Kohno K, Tanimura H, et al: Enhanced expression of the human multidrug resistance 1 gene in response to UV light irradiation. Cell Growth Differ 4: 147-157, 1993.

23. Bargou RC, Jurchott K, Wagener C, et al: Nuclear localization and increased levels of transcription factor YB-1 in primary human breast cancers are associated with intrinsic MDR1 gene expression. Nat Med 3: 447-450, 1997.

24. Lange $\mathrm{C}$, Walther W, Schwabe $\mathrm{H}$ and Stein U: Cloning and initial analysis of the human multidrug resistance-related MVP/ LRP gene promoter. Biochem Biophys Res Commun 278: $125-133,2000$.

25. Stein U, Bergmann S, Scheffer GL, et al: YB-1 facilitates basal and 5-fluorouracil-inducible expression of the human major vault protein (MVP) gene. Oncogene 24: 3606-3618, 2005.

26. Kitazono M, Sumizawa T, Takebayashi Y, et al: Multidrug resistance and the lung resistance-related protein in human colon carcinoma SW-620 cells. J Natl Cancer Inst 91: 1647-1653, 1999.

27. Carmichael J, DeGraff WG, Gazdar AF, Minna JD and Mitchell JB: Evaluation of a tetrazolium-based semiautomated colorimetric assay: assessment of chemosensitivity testing. Cancer Res 47: 936-942, 1987.

28. Zheng CL, Sumizawa T, Che XF, et al: Characterization of MVP and VPARP assembly into vault ribonucleoprotein complexes. Biochem Biophys Res Commun 326: 100-107, 2005.

29. Nakajima Y, Gotanda T, Uchimiya H, et al: Inhibition of metastasis of tumor cells overexpressing thymidine phosphorylase by 2-deoxy-L-ribose. Cancer Res 64: 1794-1801, 2004.

30. Okamoto M, Ono M, Uchiumi T, et al: Up-regulation of thrombospondin-1 gene by epidermal growth factor and transforming growth factor beta in human cancer cells - transcriptional activation and messenger RNA stabilization. Biochim Biophys Acta 1574: 24-34, 2002.

31. Schroeijers AB, Siva AC, Scheffer GL, et al: The M(r) 193,000 vault protein is up-regulated in multidrug-resistant cancer cell lines. Cancer Res 60: 1104-1110, 2000.

32. Chen J, Yang R and Liu F: Establishment of cisplatin-induced multidrug resistant human epithelial ovarian cancer cell line $3 \mathrm{AO} / \mathrm{cDDP}$ and its expression of multidrug resistance proteins. Zhonghua Fu Chan Ke Za Zhi 35: 617-620, 2000

33. Cheng G, Li Y and Tian F: Comparison of stepwise and pulse induced cisplatin-resistant ovarian cancer cell sublines. Zhonghua Zhong Liu Za Zhi 23: 305-308, 2001. 
34. Moran E, Cleary I, Larkin AM, et al: Co-expression of MDRassociated markers, including P-170, MRP and LRP and cytoskeletal proteins, in three resistant variants of the human ovarian carcinoma cell line, OAW42. Eur J Cancer 33: 652-660, 1997.

35. Laurencot CM, Scheffer GL, Scheper RJ and Shoemaker RH: Increased LRP mRNA expression is associated with the MDR phenotype in intrinsically resistant human cancer cell lines. Int J Cancer 72: 1021-1026, 1997.

36. Verovski VN, Van den Berge DL, Delvaeye MM, Scheper RJ, De Neve WJ and Storme GA: Low-level doxorubicin resistance in P-glycoprotein-negative human pancreatic tumour PSN1/ADR cells implicates a brefeldin A-sensitive mechanism of drug extrusion. Br J Cancer 73: 596-602, 1996.

37. Versantvoort CH, Withoff S, Broxterman HJ, et al: Resistanceassociated factors in human small-cell lung-carcinoma GLC4 sub-lines with increasing adriamycin resistance. Int J Cancer 61: 375-380, 1995.

38. Mossink MH, van Zon A, Franzel-Luiten E, et al: Disruption of the murine major vault protein (MVP/LRP) gene does not induce hypersensitivity to cytostatics. Cancer Res 62: 7298-7304, 2002.

39. Asakuno K, Kohno K, Uchiumi T, et al: Involvement of a DNA binding protein, MDR-NF1/YB-1, in human MDR1 gene expression by actinomycin D. Biochem Biophys Res Commun 199: 1428-1435, 1994

40. Ohga T, Uchiumi T, Makino Y, et al: Direct involvement of the Y-box binding protein YB-1 in genotoxic stress-induced activation of the human multidrug resistance 1 gene. J Biol Chem 273: 5997-6000, 1998.
41. Ise T, Nagatani G, Imamura T, et al: Transcription factor Y-box binding protein 1 binds preferentially to cisplatin-modified DNA and interacts with proliferating cell nuclear antigen. Cancer Res 59: 342-346, 1999.

42. Oda Y, Sakamoto A, Shinohara N, et al: Nuclear expression of YB-1 protein correlates with P-glycoprotein expression in human osteosarcoma. Clin Cancer Res 4: 2273-2277, 1998.

43. Steiner E, Holzmann K, Pirker C, Elbling L, Micksche M and Berger W: SP-transcription factors are involved in basal MVP promoter activity and its stimulation by HDAC inhibitors. Biochem Biophys Res Commun 317: 235-243, 2004.

44. Emre N, Raval-Fernandes S, Kickhoefer VA and Rome LH: Analysis of MVP and VPARP promoters indicates a role for chromatin remodeling in the regulation of MVP. Biochim Biophys Acta 1678: 33-46, 2004.

45. Mossink M, van Zon A, Franzel-Luiten E, et al: The genomic sequence of the murine major vault protein and its promoter. Gene 294: 225-232, 2002.

46. Bork P, Hofmann K, Bucher P, Neuwald AF, Altschul SF and Koonin EV: A superfamily of conserved domains in DNA damage-responsive cell cycle checkpoint proteins. FASEB J 11: 68-76, 1997.

47. Callebaut I and Mornon JP: From BRCA1 to RAP1: a widespread BRCT module closely associated with DNA repair. FEBS Lett 400: 25-30, 1997. 